\title{
IMPLEIMENTASI TRILOGI SANTRI DALAMI MENUMBUHKAN KESADARAN BERBANGSA DAN BERNEGARA SANTRI PONDOK PESANTREN NURUL JADID PAITON PROBOLINGGO
}

\author{
Moch. Tohet, Havivatus Shalihah \\ Universitas Nurul Jadid Paiton Probolinggo \\ elheds78@gmail.com, havivatuss@gmail.com
}

\begin{abstract}
Changes that occur due to globalization affect the entire existing order, an era that will not be separated from the negative and positive elements. One of them is the influence of young people on things that are not good, as well as on morals and attitudes of human behavior. Through education, especially pesantren education, the government seeks to fortify young people with role models of life in the nation and state. This study aims to explain the role of the Santri Trilogy in fostering national and state awareness of the students of the Nurul Jadid Paiton Probolinggo boarding school. This research uses descriptive qualitative approach type case study method. Based on the results of the study, it is known that several important points in fostering national and state awareness are through the cultivation of habits in daily life in the form of making mandates mandatory, obeying pesantren regulations, and mutual cooperation. And the efforts made by the government through instilling national and state awareness, being involved in state activities, and holding national seminars.
\end{abstract}

Keywords: Santri, Santri Trilogy, National and State Awareness

\section{PENDAHULUAN}

Seiring berkembangnya zaman yang tak lepas dari sekian banyak peradaban didalam hingga pada era globalisasi peradaban modern, yang membuat banyak orang tercengang dengan banyaknya fenomena yang terjadi baik dari segi positif ataupun negatif. Tak bisa dipungkuri dengan bergulirnya peradaban modern ini, setidaknya sedikit banyak telah mempengaruhi moral anak bangsa yang semakin hari mengalami kemerosotan, dan dari waktu ke waktu menyebabkan nilai luhur bangsa Indonesia mulai terkikis ${ }^{1}$.

Kondisi ini bisa dilihat dari lunturnya nilai-nilai cinta tanah air yang disebabkan oleh masuknya produk luar ke Indonesia. Seperti halnya, generasi muda lebih percaya diri bila mana ia memiliki dan menggunakan barang dari luar negeri, semakin maraknya pula aktor-aktor perfilman luar negeri yang dikagumi oleh muda-mudi bangsa ini. Mereka lebih tertarik dengan budaya-budaya impor dari negara-negara luar .Kecintaan kepada

1 Astri Wahyuni et al., "Peran Etnomatematika Dalam Membangun Karakter Bangsa:," Penguatan Peran Matematika Dan Pendidikan Matematika Untuk Indonesia Yang Lebih Baik, no. 1 (2013): 111-18. 
budaya lokal telah dikalahkan oleh kesukaan kepada budaya-budaya impor tersebut, bukan hanya produk-produk yang bersifat fisik material, tapi juga berupa adat istiadat, lifestile dan lain-lain.

Para pejabat pun, yang seharusnya menjadi contoh dan panutan yang baik justru malah sebaliknya. Sehingga sangat biasa terdengar dan tayang di awak media negeri ini, terjadinya korupsi dikalangan para pejabat tinggi yang seakan sudah menjadi ideologi baru bagi para maling berdasi. Hal inilah yang menjadi faktor pendukung merosotnya akhlak dan moral serta terkikisnya nilai-nilai luhur bangsa Indonesia, dan pada gilirannya akan memperlemah rasa kebangsaan kita.

Fenomena-fenomena itu terjadi, disebabkan nilai religius dan nilai budaya bangsa belum sepenuhnya dijadikan pijakan oleh sebagian masyarakat Indonesia, sehingga menjadi sebab lunturnya akhlak dan moral masyarakat Indonesia. Banyaknya fenomena yang terjadi jika tidak ada tindakan dan solusi yang cerdas maka bisa dipastikan akan menimbulkan masalah yang lebih rumit kedepannya bagi bangsa Indonesia. Fenomena sosial tersebut membutuhkan perhatian yang sangat serius dari berbagai kalangan, terutama dari kalangan pemerhati pendidikan.

Kualitas sebuah pendidikan menjadi tolak ukur kemajuan suatu bangsa/pemudanya. Generasi muda adalah tiang kokoh suatu bangsa dimasa mendatang. Sebagaimana sebuah ungkapan "Education is the largest field of investment in building and shaping men". Yang artinya Pendidikan adalah ladang investasi terluas dalam membangun dan membentuk pemuda. Maka, melalui pendidikan kita bisa berinvestasi dalam membangun dan membentuk pemuda sesuai dengan apa yang dicita-citakan oleh bangsa dan negara.

Maka saat seperti sekarang ini, pendidikan kerakter sangatlah relevan dipraktekkan untuk mengatasi krisis kemerosotan akhlak dan moral yang perlahan telah mulai luntur pada pribadi masyakatat Indonesia. Dengan direalisasikannya pendidikan karekter di masa-masa peradaban modern ini, diharapkan dapat menumbuhkan kembali nilai agama, budaya bangsa dan moral serta dapat mambentuk pribadi-pribadi yang bertanggung jawab dan sadar akan pentingnya berakhlak dan bermoral dalam etika berbangsa dan bernegara. ${ }^{3}$

Pesantren merupakan salah satu solusi dalam menumbuhkan akhlak dan moral dalam berbangsa dan bernegara. Pendidikan pesantren disebut sebagai "bapak" dari pendidikan Islam di Indonesia atau juga dikenal dengan istilah Indegeneus Culture ${ }^{4}$, yang didirikan karena adanya tuntutan dan kebutuhan zaman, dari tingginya kesadaran dakwah islamiyah para ulama-ulama terdahulu untuk menyebarluaskan dan meluaskan ajaran

${ }^{2}$ Syaiful Islam et al., "To Boost Students ' Motivation and Achievement through Blended Learning," Journal of Physics: Conf. Series 1114, 2018, 1-11.

3 Muhammad Kristiawan and Yeni Wulandari, "Strategi Sekolah Dalam Penguatan Pendidikan Karakter Bagi Siswa Dengan Memaksimalkan Peran Orang Tua," Jurnal Manajemen, Kepemiminan, Dan Supervisi Pendidikan (JMKSP) 2, no. 2 (2017): 290-303.

${ }^{4}$ Nur Jamal, "Transfoormasi Pendidikan Pesantren Dalam Pembentukan Kepribadian Santri," Tarbiyatuna: Jurnal Pendidikan Islam 8, no. 2 (2015): 64-100. 
Islam sekaligus untuk membentuk kader-kader ulama' dan da'i yang benar dan baik dari segi keilmuan, akhlak dan moral. ${ }^{5}$

Dalam pola pendidikannya, pesantren memiliki ciri khas tersendiri dalam mendidik para peserta didiknya (santri), yaitu konsen pada pengembangan karakter yang menjadi titik fokus pengembangan yang terkait erat dengan visi dan misi yang hendak dicapai pesantren. Peserta didik dipesantren, tidak hanya dituntut untuk menguasai materi-materi pelajaran seperti pada umumnya. Akan tetapi dalam dunia pesantren, peserta didik (santri) diajar dan ditanamkan pada pribadi-pribadi santri pendidikan akhlak dan moral. Dunia pesantren (pendidikan pesantren) adalah solusi yang tepat, relevan dan perlu mendapat porsi besar dikalangan masyarakat. Nilai-nilai religius diharapkan dapat menjadi pijakan dalam mencetak pribadi yang baik, serta diharapkan dapat menumbuhkan karakter bangsa dan menunjang kemampuan/life skill siswa dengan mengukur segala sesuatu dari sudut pandang agama ${ }^{6}$.

Salah satunya di Pondok Pesantren Nurul Jadid Paiton Probolinggo. KH. Zaini Mun'im ${ }^{7}$ memiliki pemikiran tentang kemajuan suatu bangsa dan kemakmuran bagi masyarakat Indonesia, yang tertuang dalam kurikulum 3-5 yakni, Trilogi Santri dan Panca Kesadaran Santri. Trilogi Santri merupakan tiga prinsip hidup KH. Zaini Mun'im yang bercita-cita untuk menjadikan masyarakat Indonesia menjadi masyarakat pesantren. Sedangkan Konsep Panca kesadaran Santri merupakan gagasan yang merupakan manifestasi dari kajian teoritisnya, perenungan, dan pengalaman beliau di dunia dakwah. ${ }^{8}$

${ }^{5}$ Hasbullah, Sejarah Pendidikan Islam di Indonesia, (Jakarta: Lembaga Studi Islam dan Kemasyarakatan LKIS, 1999), h. 138.

${ }^{6}$ Y. Wulandari and M. Kristiawan, "Strategi Sekolah Dalam Penguatan Pendidikan Karakter Bagi Siswa Dengan Memaksimalkan Peran Orang Tua," JMKSP (Jurnal Manajemen, Kepemimpinan, Dan Supervisi Pendidikan) 2, no. 2 (2017): 290-302.

${ }^{7}$ KH. Zaini Mun'im adalah pendiri dan pengasuh pertama Pondok Pesantren Nurul Jadid Paiton Probolinggo. Dilahirkan di Desa Galis Pamekasan Madura pada tahun 1906. Beliau merupakan putra pertama dari pasangan KH. Abdul Mun'im dan Ny. Hj. Hamidah. Dalam tubuhnya mengalir darah bangsawan dan darah ulama yang mempunyai komitmen pada nilai-nilai ajaran Islam, baik dari ayahanda maupun dari jalur ibundanya. Lebih-lebih, jika diruntut, silsilahnya sampai kepada Rasulullah SAW melalui Bindere Sa'ud (Bendoro Saud). Dalam diri KH. Zaini tertanam jiwa pejuang. Hal ini tergambar sejak masa mudanya, terutama setelah beliau pulang dari tanah suci Makkah pada tahun 1934. Ketika itu, beliau memperhatikan berbagai persoalan yang melilit kehidupan bermasyarakat sekitarnya dan terlibat langsung dalam kancah perjuangan kemerdekaan Indonesia. Untuk memperjuangkan kepentingan masyarakat banyak, beliau bergabung dalam organisasi NU (Nahdlatul Ulama) di Pamekasan. Beliau tidak segan-segan ikut terjun langsung menangani berbagai persoalan yang dihadapi masyarakat. Terutama tentang kebijakan kolonial Belanda di bidang pertanian (tembakau). Setelah hijrah dan menetap di Tanjung Paiton Probolinggo, perjuangannya di NU pun terus berlanjut. Pada masa penjajahan Jepang dan Belanda beliau juga aktif terlibat dalam perjuangan mempertahankan NKRI bersama masyarakat. Dipercayai sebagai pimpinan Barisan pembela Tanah Air (PETA) pada masa penjajahan Jepang dan ketika masa penjajahan Belanda, beliau juga dipercaya sebagai pimpinan Sabilillah ketika melakukan Serangan Umum pada tanggal 16 Agustus 1947 terhadap bala tentara Belanda yang menguasai kota Pamekasan, Madura. belakang

${ }^{8}$ KH. Zaini Mun'im, problematika Dakwah Islamiyah (Probolingggo: NJPress, 2008) cover 
Dari kelima Panca Kesadaran Santri, kesadaran berbangsa dan bernegara merupakan bentuk kesadaran ke empat yang dirumuskan oleh pendiri Pondok Pesantren Nurul Jadid Paiton Probolinggo. Hal ini menjadi bukti bahwa santri Nurul Jadid diharapkan mampu mempunyai rasa nasionalisme yang tinggi terhadap bangsa Indonesia. Maka perlu kiranya mengetahui bagaimana menumbuhkan kesadaran berbangsa dan bernegara yang diimplementasikan melalui Trilogi Santri.

\section{METODE PENELITIAN}

Penelitian ini menggunakan metode deskriptif pendekatan kualitatif jenis study kasus(case study) ${ }^{9}$. Maka, instrument penelitiannya adalah peneliti itu sendiri. Bertujuan menggambarkan secara sistematis fakta dan karakteristik objek yang diteliti. Menyelidiki fenomena dalam konteks kehidupan nyata yakni, menggambarkan sifat individu secara tepat dan keadaan sosial yang timbul di masyarakat.

Penelitian ini dilaksanakan di Pondok Pesantren Nurul Jadid Paiton Probolinggo. Sumber. Subjek penelitian adalah seluruh santri Pondok Pesantren Nurul Jadid Paiton Probolinggo. Teknik pengumpulan data dengan menggunakan interview, observasi, dan dokumentasi yang mendalam guna mendapatkan informasi secara langsung. Data-data yang dijadikan acuan dalam penelitian ini adalah data kepustakaan dan data lapangan. Yang diharapkan dapat menghasilkan deskripsi yang baik tentang perilaku yang diamati, sehingga tergambar dengan jelas bagaimana peran Trilogi Santri dalam menumbuhkan keasadaran berbangsa dan bernegara.

\section{HASIL PENELITIAN DAN PEMBAHASAN}

\section{A. Hakikat Santri}

Dalam Kamus Besar Bahasa Indonesia, santri diartikan orang yang mendalami Islam, orang yang beribadat dengan sungguh-sungguh; orang yang soleh ${ }^{10}$. Dan menurut Sindu Galbu santri ialah orang yang mendalami pengajian dalam Islam dengan berguru ke tempat yang jauh seperti pesantren ${ }^{11}$.

Menurut pandangan Said Aqil Siradj dalam buku Lanny Octavia menyatakan istilah "santri" konon berasal dari bahasa sanskerta "shastri" artinya orang yang belajar kalimat suci dan indah, yang kemudian diadopsi oleh kalangan wali songo sebagai santri. Jadi santri adalah orang yang belajar kalimat suci dan indah yang menurut Wali Songo belajar kitab suci Al-Qur'an dan hadis. Lalu, kalimat-kalimat tersebut kemudian diajarkan, dipahami, dan diaplikasikan dalam kehidupan sehari-hari ${ }^{12}$.

\footnotetext{
${ }^{9}$ Nana Sudjanadan Ibrahim, Penelitian Dan Penilaian Pendidikan, 2nd ed. (Bandung: Sinar Baru Algesindo, 2001). h. 7.

10 "Kamus Besar Bahasa Indonesia Online," n.d., https://www.kbbi.web.id/negara.

${ }^{11}$ Sindu Galba, Pesantren Sebagai Wadah Komunikasi, 2nd ed. (Jakarta: Rineka Cipta, 1995). h. 1

${ }^{12}$ Dkk Lanny Oktavia, Pendidikan Karakter Berbasis Tradisi Pesantren Kumpulan Bahan Ajar, 1st ed. (Jakarta: Rumah Kitab, 2014). h. xi.
} 
Ada pula yang mengartikan santri adalah gabungan dari huruf Arab Sin, Nun, Ta', Ra', dan Ya'. Yang memiliki arti tersendiri yakni: Sin(w) artinya Salik Al Akhirah (الَْخِرَة (menempuh jalan spiritual menuju akhirat). Para santri memiliki orientasi yang jelas dalam hidupnya. Ia meyakini bahwa semua makhluk sejarahnya bukan di bumi, bukan di dunia, melainkan di akhirat. Sehingga apapun yang dilakukan santri sematamata hanya demi kebahagian di akhirat. Nun (ن) maknanya Na'ib an Al Masyayikh (نَيَّبُ الَْنَشَايخخ (penerus para guru). Santri merupakan penerus estafet perjuangan para ulama terdahulu yang ketika kembali kepada masyarakat diharapkan dapat menjadi rohaniawan Islam. Ta' (تُرَكِ الْمَعَاصِي)(meninggalkan maksiat). Santri selalu identik dengan penyucian rohani, kesederhanaan dan menjauhi dosa. Seperti yang kita ketahui, di pesantren santri selalu diajarkan hidup sederhana dan menjauhi perbuatan yang dapat menghantarkan kepada dosa. Ra' (ر) (ر) akronim dari Raghib Al Khayr (رَغَبُ الََْيْر)(selalu menghasrati kebaikan). Dipesantren para santri diajarkan untuk selalu berbuat kebaikan, sudah seharusnya santri menjadi pelopor kebaikan. Sebab dalam lingkungan pesantren tidak hanya diajarkan untuk pandai menguasai pelajaran melainkan juga dituntut untuk dapat bermoral baik terhadap sesama. Nilai-nilai kebaikan diadopsi dari perilaku kharismatik kiai, yang di contohkan dalam kehidupan sehari-hari yang mengarah kepada tiga unsur pokok pembentukan karakter, yaitu mengetahui kebaikan, mencintai kebaikan dan melakukan kebaikan. ${ }^{13} Y a$ ' (ي) adalah singkatan dari Yarjus As Salamah (يَرْجُ السَّلَََّة)(optimis terhadap keselamatan). Filosofis kelima dari santri yaitu selalu optimis setiap menjalani hidup dan mengharapkan keselamatan dunia ataupun di akhirat. ${ }^{14}$.

Secara formal santri adalah orang yang menempuh pendidikan dan pembelajaran di pondok pesantren kepada seorang kiai, untuk mendapatkan ilmu dan pendidikan khususnya dalam bidang agama (khususnya agama Islam) disamping ilmu-ilmu yang lain yang diperlukan agar hidup sejahtera baik di dunia maupun diakhirat kelak dan biasanya menetap hingga menuntaskan pendidikannya ${ }^{15}$, yang menurut pendapat Zamankhsyari Dhofier disebut dengan santri mukim ${ }^{16}$. Namun, secara substansial santri adalah orang yang memahami ajaran Islam dan mengamalkannya serta berupaya menyebarkannya di tengah masyarakatnya sebagai bentuk ibadah kepada Allah dan pengabdian sesama sekalipun mungkin tidak pernah belajar di pesantren, dan dari sinilah muncul sebutan makna kolektif yakni "kaum santri"17.

13 Feri Jon Nasrullah, "Pendidikan Karakter Pada Anak Dan Remaja," Jurnal Seminar Psikologi Dan Kemanusiaan, 2015, 483-86.

14 Ach. Dhofir Zuhry, Peradaban Sarung = Veni, Vidi, Santri (Jakarta: Elex Media Komputindo, 2018). h. 5-8.

${ }^{15}$ Sukamto, Kepemimpinan Kiai Dalam Pesantren (Jakarta: Pustaka LP3ES, 1999). h. 97.

${ }^{16}$ Zamankhari Dhofier, TRADISI PESANTREN (Studi Pandangan Hidup Kyai Dan Visinya Mengenai Masa Depan Indonesia) (Jakarta: LP3ES, anggota Ikapi, 2015). h. 89.

17 Jamali, Kaum Santri Dan Tantangan Kontemporer”, Dalam Pesantren Masa Depan: Wacana Pemberdayaan Dan Transformasi Pesantren, Ed. Said Aqiel Siradj (Bandung: Pustaka Hidayah, 1999). h. 130 
Santri merupakan salah satu dari lima elemen pokok sebuah pondok pesantren yang membedakannya dengan lembaga pendidikan pada umumnya. Santri merupakan komposisi penting dalam lembaga pendidikan pesantren, karena hal awal dalam sebuah pesantren ialah harus ada santri yang datang untuk menimba ilmu agama kepada seorang kiai. Santri merupakan salah satu keunikan islam yang dimiliki oleh negara/bangsa Indonesia, yang jarang di temukan di belahan bumi manapun. Santri adalah pelajar yang sederhana dan bersahaja, rela berbaur, mengabdi ditengah-tengah masyarakat tanpa mengharapkan formalitas dan formalisme yang tinggi. ${ }^{18}$

Pada sisi lain, dengan latar belakang para santri yang berasal dari berbagai etnis suku bangsa dan budaya, ras, serta bahasa yang berbeda-beda berdasarkan daerah masingmasing sehingga menjadikan para santri diharuskan untuk menghargai satu sama lain dan saling toleransi antar sesama sebagaimana arti dari kebhinekaan. Para santri diajarkan untuk berbaur dengan masyarakat luas terlebih dalam hal bangsa dan bernegara. Menghargai perbedaan, antara suku, ras, bahasa, serta mewujudkan pergaulan yang baik, seperti halnya keikhlasan, kesederhanaan, kemandirian, ukhuwah islamiyyah, ukhuwah wathaniyahh yang diharapkan mampu mempertahankan warisan budaya tradisional dan bercorak kearifan lokal, inilah yang menjadi output dari pendidikan pesantren kepada para santrinya. ${ }^{19}$

\section{B. Trilogi Santri}

Secara etimologi, tri artinya tiga sedangkan logi artinya studi atau ilmu. Sedangkan santri adalah orang yang menimba ilmu pengetahuan kepada seorang kiai di pondok pesantren. Jadi, Trilogi Santri adalah tiga dasar ilmu amaliah yang di susun oleh pendiri Pondok Pesantren Nurul Jadid untuk dijadikan landasan bagi santri terutama dalam hal ibadah. Baik ibadah mahdlah dan ghairu mahdlah ${ }^{20}$.

Trilogi Santri adalah standar kompetensi dasar yang harus dikuasai oleh setiap santri Pondok Pesantren Nurul Jadid. Trilogi Santri dijadikan tolak ukur sebuah kesantrian. Maka dari itu, sebagai standar kompetensi dasar, santri wajib memahami, mengahayati, dan mengimplementasikan dalam kehidupan sehari-hari. Trilogi Santri dan Panca Kesadaran Santri saat ini mulai direvitalisasi kembali oleh kepala Pesantren KH. Abdul Hamid Wahid dan Biro Pendidikan guna menghidupkan kembali pemikiranpemikiran KH. Zaini yang disebut dengan kurikulum 3-5.

Trilogi santri adalah penjabaran praktis implementatif dari salah satu point dari Panca Kesadaran Santri yaitu Kesadaran Beragama. Trilogi Santri terdiri dari tiga point;

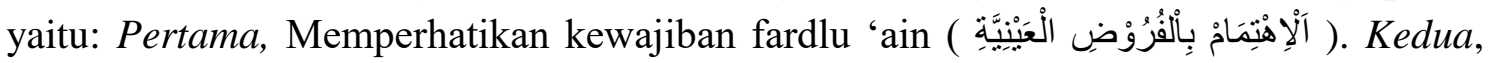

${ }^{18}$ Zuhry, Peradaban Sarung = Veni, Vidi, Santri. h. 3

19 A Muchaddam Fahham, "Pendidikan Karakter Di Pesantren (Character Education in Islamic Boarding School)," Aspirasi 4, no. 1 (2013): 29-45.

${ }^{20}$ Saifur Rizal, "Servant Leadership Dalam Implementasi Nilai-Nilai Trilogi Dan Panca Kesadaran Santri," Journal EVALUASI 3, no. 2 (2019): 162, https://doi.org/10.32478/evaluasi.v3i2.251. 


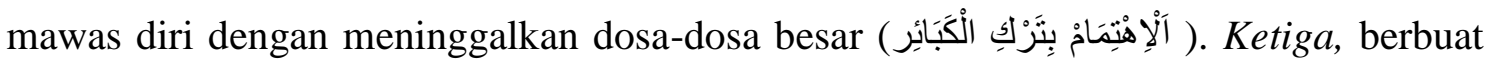

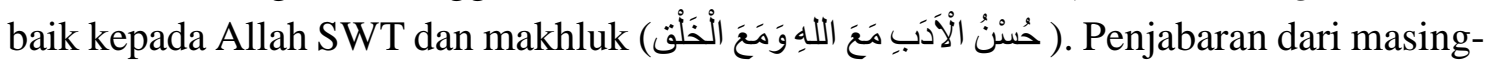
masing Trilogi Santri adalah sebagai berikut:

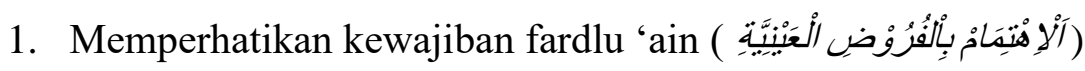

Artinya sebagai masyarakat (santri) harus selalu mementingkan permasalahan agama yang hukumnya fardu ain. Sebagaimana di ketahui bersama bahwa manusia dikenai kewajiban-kewajiban yang melekat pada manusia sendiri, seperti kewajiban manusia kepada tuhannya, dalam hal ini seperti ibadah, sholat, dan juga kewajiban kepada sesama manusia seperti zakat, dan lain-lain.

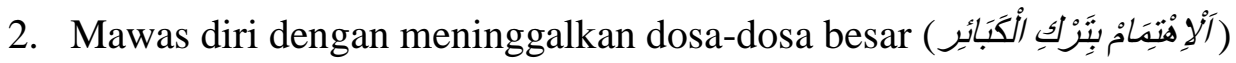

Artinya sebagai masyarakat (santri) harus memiliki pendirian yang teguh dalam menjauhi dosa besar. Sebagai seorang muslim yang bertaqwa seharusnya kita menjauhi perkara-perkara yang akan merusak iman, apabila perbuatanperbuatan tersebut dikerjakan maka akan mendatangkan dosa besar dan berdampak tidak baik bagi seseorang tersebut. Seperti halnya membunuh, berzina, minum-minuman keras, dan lain sebagainya.

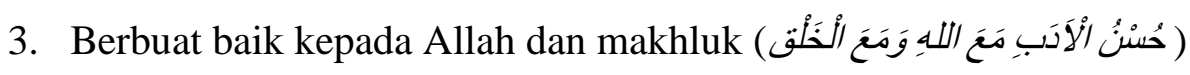

Artinya sebagai masyarakat (santri) senantiasa menjaga dan meningkatkan hubungan baik dengan Allah dan makhluk-Nya. Manusia sebagai ciptaan Allah SWT terikat oleh aturan-aturan syari'at yang harus dipatuhi sesuai dengan ketetapan yang telah diatur. Di dalam Al-Qur'an dijelaskan manusia diciptakan dari berpasangan laki-laki dan perempuan, bersuku-suku, berbangsa-bangsa untuk saling berinteraksi (membangun hubungan baik dengan sesama), dan juga berperan untuk memakmurkan dunia ini, dan yang paling utama adalah manusia sepatutnya menyembah dan bertuhankan kepada Allah SWT. Oleh sebab itu Manusia harus memahami posisi, peran dan kedudukannya ketika hidup didunia ini. ${ }^{21}$

Penuturan K.H. Zuhri Zaini terkait trilogi santri: "Berupaya menjalankan kewajiban-kewajiban dan menjauhi larangan-larangan, maka harus berakhlakul karimah kepada siapapun dan kepada apapun, ya kepada Allah, kepada manusia, bahkan dengan makhluk-makhluk yang lain termasuk pada lingkungan tentu disesuaikan ya, misalnya saling menghormati, tidak saling mengganggu, bahkan saling menyayangi, juga kepada para makhluk yang lain juga menghargai, dengan tidak menyakiti, tidak menyiksa. Menjaga kebersihan lingkungan juga merupakan akhlakul karimah. Dan hal yang paling utama kepada tuhan, kita harus bersyukur dan menerima segala sesuatu yang diberikan dan yang kita dapatkan, antara lain. Yang ke 3 (tiga) yaitu berakhlak baik kepada semuanya pasti kehidupannya akan harmonis, tidak ada konflik"22.

${ }^{21}$ M Syaiful Suib, "ISLAM DAN INDONESIA MENURUT KH . ZAINI MUN' IM : Wawasan Tentang Islam," At-Turas V, no. 2 (2018): 263-83.

22 Syaifullah and Totok Suyanto, "Aktualisasi Nilai-Nilai Multikultural Di Pondok Pesantren,” Jurnal Kajian Moral Dan Kewarganegaraan 3, no. 2 (2014): 1061-75. 
Trilogi Santri dijadikan pedoman hidup para santri di Pondok Pesantren Nurul Jadid Paiton Probolinggo. Dengan adanya Trilogi Santri diharapkan para santri akan menghafal, memahami serta menghayati dalam kehidupan sehari-hari. Selain itu, trilogi santri dapat menjadi pedoman bagi santri dalam menjalankan kewajibannya di pesantren sebagai santri serta dapat mendorong santri dalam mendalami ilmu tidak hanya untuk dimiliki atau dikuasai, melainkan untuk diamalkan. Trilogi santri juga dapat dijadikan pegangan, pedoman hidup ketika sudah kembali kepada masyarakat dalam menghadapi berbagai problem, tantangan, situasi dan kondisi disekitar. Sehingga tumbuh kepribadian santri yang "berilmu amaliah, beramal ilmiyah" dan berakhlaqul karimah.

\section{Kesadaran Berbangsa dan Bernegara}

Sadar berarti insaf, merasa, tahu dan mengerti ${ }^{23}$. Secara sederhana dapat dinyatakan bahwa kesadaran merupakan daya hidup manusia dan menjadi tumpuan seseorang dalam mempertimbangkan perilaku. Kesadaran merupakan kondisi mencerminkan adanya otonomi dalam pengambilan keputusan manusia ${ }^{24}$.

Dalam Kamus Besar Bahasa Indonesia bangsa diartikan sebagai kelompok masyarakat yang bersamaan asal keturunan, adat, bahasa, dan sejarahnya, serta berpemerintahan sendiri. Sedangkan negara adalah organisasi dalam suatu wilayah yang mempunyai kekuasaan tertinggi yang sah dan ditaati oleh rakyat ${ }^{25}$. Jadi, berbangsa dan bernegara merupakan suatu Prioritas Rakyat/Individu untuk menjaga persamaan cita" bangsa Indonesia. Maka dalam menjaga cita" bangsa Indonesia di butuhkan tata tertib yang di atur oleh suatu organisasi dari suatu kelompok atau beberapa kelompok untuk mengetahui perkembangan cita" bangsa dan menjaga cita" bangsa indonesia.

Sebagai warga yang hidup dan terikat dalam lindungan Negara Kesatuan Republik Indonesia, maka harus mempunyai sikap dan perilaku yang tumbuh dari kemauan diri yang dilandasi keikhlasan/kerelaan bertindak demi kebaikan bangsa dan negara Indonesia.

Dalam Kamus Tesaurus Bahasa Indonesia, cinta tanah air dipadankan dengan nasionalisme dan patriotisme. Secara etimologis kata nasionalisme, berasal dari akar kata national yang diambil dari natio yang berarti bangsa yang dipersatukan karena kelahiran. Kata natio berasal kata nascie yang berarti dilahirkan. Nation atau bangsa menurut Hans Kohn adalah golongan-golongan yang beragam dan tidak dapat dirumuskan secara pasti. ${ }^{26}$ Sedangkan dalam bahasa Arab cinta tanah air disebut Al-Wathaniyyah (kebangsaan) atau hubb al-wathan (nasionalisme).

23 "Kamus Besar Bahasa Indonesia Online."

24 H. Agung Hartoyo, "Menggugah Kesadaran Nasional Mempengarui Kebhinekaan Indonesia," Jurnal Pendidikan Sosiologi Dan Humaniora 1, no. 2 (2019): 132-47.

25 "Kamus Besar Bahasa Indonesia Online."

${ }^{26}$ Abdul Choliq Murod, "NASIONALISME " DALAM PESPEKTIF ISLAM," Jurnal Sejarah CITRA LEKHA XVI, no. 2 (2011): 45-58. 
Dalam kehidupan keagamaan, agama mengatur kehidupan umatnya dalam berbangsa dan bernegara. Paham kebangsaan baru muncul dan berkembang di Eropa sejak abad ke-18, dan dari sana menyebarlah keseluruh dunia Islam. Paham kebangsaan ini mula-mula diperkenalkan oleh Napoleon kepada umat Islam pada saat ekspedisinya ke mesir ${ }^{27}$. Paham kebangsaan yang muncul di negara yang mayoritas penduduknya muslim muncul dari perlawanan terhadap penjajahan. Nasionalisme dalam Islam dijelaskan dalam Al-Qur'an surat al-Baqarah/2:126: ${ }^{28}$

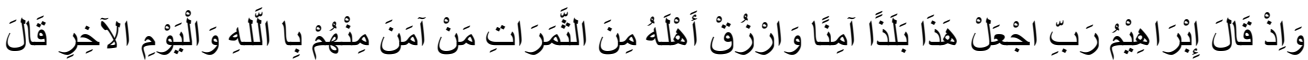

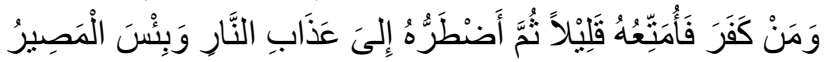

Terjemahannya:

Dan ingatlah, ketika Ibrahim berdoa, Ya tuhanku, jadikanlah negeri ini negeri yang aman sentosa, dan berikanlah rezeki dari buah-buahan kepada penduduknya yang beriman diantara mereka kepada Allah dan hari kemudian. Allah berfirman, "dan kepada orang yang kafir pun aku beri kesenangan sementara." (QS. Al-Baqarah $2: 126)$

Dalil diatas yang mendasari KH. Zaini Mun'im merumuskan konsep kesadaran berbangsa dan bernegara yang merupakan landasan filosofis ${ }^{29}$ Pondok Pesantren tidak hanya mendoktrin para santri untuk menjadi generasi berbobot di bidang kognitif, akan tetapi para santri dibimbing untuk membentuk sikap dan kepribadian santri sesuai dengan tuntunan, ajaran, dan nilai-nilai Islam. Dalam literatur pendidikan pesantren terdapat ungkapan hubbul wathon minal iman (cinta tanah air sebagian dari iman) ${ }^{30}$.

Bangsa Indonesia memiliki keinginan membangun sebuah peradaban yang telah dirumuskan dan telah disepakati bersama oleh the founding father. Dengan menanamkan rasa sikap kebangsaan dan cinta tanah air terhadap nusa dan bangsa diharapkan terciptanya warga negara yang utuh secara sepenuh hati mencintai negaranya. Arah dan cita-cita peradaban tersebut tertuang dalam konsep empat pilar kehidupan berbangsa dan bernegara yakni, Pancasila, UUD 1945, Bhineka Tunggal Ika, dan NKRI. Pancasila merupakan karakter bangsa Indonesia, yang membedakannya dengan bangsa lainnya.

Pancasila sebagai jiwa bangsa (Volksgeist), sebagai jati diri bangsa (innerself of nation) dan menjadi cara hidup (way of life) bangsa Indonesia ${ }^{31}$. Pancasila juga mengatur

${ }^{27}$ M. Quraish Shihab, Wawasan Al-Qur'an Tafsir Tematik Atas Pelbagai Persoalan Umat (Bandung: Mizan Pustaka, 1996). h. 435. 2015). h. 19.

${ }^{28}$ Depatemen Agama RI, Al-Qur'an Hafalan Dan Terjemahannya, 1st ed. (Jakarta: almahira,

29 Saili Aswi dkk, Riwayat Singkat Almarhumin Pondok Pesantren Nurul Jadid, (Probolinggo, Sekretariat PPNJ, 2011),h. 14.

${ }^{30}$ M. Masyhur Amin, NU \& Ijtihad Politik Kenegaraannya (Yogyakarta: Al-Amin Press, 1996). h. 31 .

${ }^{31}$ Syahrial Syarbaini, Pendidikan Pancasila Di Perguruan Tinggi Implementasi Nilai-Nilai Karakter (Bogor: Ghalia Indonesia, 2014). h. 4. 
hubungan manusia dengan tuhannya (hablumminallah), hubungan manusia dengan sesama (hablumminannaas), dan hubungan manusia dengan masyarakat atau bangsanya, dan manusia dengan alam sekitarnya (hablum minal alam).

Nasionalisme bersama berbagai nilai luhur bangsa lainnya merupakan pegangan sekaligus tumpuan dalam berperilaku guna menuju arah dan cita-cita bangsa Indonesia. Sejalan dengan hal tersebut konsep empat pilar kehidupan berbangsa dan bernegara merupakan prasyarat minimal bagi bangsa ini untuk bisa berdiri kukuh dan meraih kemajuan berlandaskan karakter kepribadian bangsa Indonesia sendiri. Setiap warga negara Indonesia harus memegang teguh, nilai-nilai luhur keindonesian yang akan memandu tercapainya perikehidupan bangsa yang merdeka, bersatu, berdaulat, adil dan makmur.

Perlu diketahui bahwa kesadaran berbangsa dan bernegara adalah salah satu point dari Panca Kesadaran yang harus dimiliki oleh seorang santri. Kesadaran berbangsa dan bernegara adalah kesadaran bahwa kita, termasuk juga para santri adalah bagian dari bangsa dan negara yang disamping mempunyai hak (manfaat) dari bangsa dan negara itu, juga punya kewajiban (tanggung jawab) terhadap bangsa dan negara kita. Misalnya menjaga kedaulatan negara, menjaga keutuhan bangsa dan negara, membangun bangsa dan negara dalam segala aspek kehidupannya, melestarikan dan menjaga lingkungan baik alam maupun sosial budaya dari kerusakan dan kepunahan; dan lain-lain. Dengan melaksanakan kewajiban maka kita sebagai warga negara berhak untuk mendapat perlindungan dan pelayanan kebutuhan kita dari negara kita baik secara fisik maupun psikis.

\section{Peran Trilogi Santri dalam Menumbuhkan Kesadaran Berbangsa dan Bernegara di Pondok Pesantren Nurul Jadid}

Pesantren diyakini sebagai satu-satunya benteng terakhir dalam penyelamatan bangsa dan negara dari keterpurukannya dengan konsep dan ajaran Islam yang moderat (tawassuth), keseimbangan (tawazun), dan toleransi (tasamuh). Dengan demikian pesantren yang memiliki pemahaman keagamaan dan anti kekerasan dengan nilai-nilai kearifan lokal yang sudah membudaya diharapkan dapat menumbuhkan kesadaran berbangsa dan bernegara.

Menumbuhkan karakter bangsa khususnya dikalangan para pemuda haruslah didahulukan, karena merekalah kelak yang akan memimpin bangsa ini. Bila para pemuda memiliki sikap nasionalisme yang tinggi tentu, bangsa ini akan menjadi bangsa yang maju. Namun seiring berjalannya waktu, semakin majunya perkembangan zaman, rasa nasionalisme para pemuda semakin memudar. Nasionalisme sangat penting terhadap kehidupan berbangsa dan bernegara karena merupakan wujud kecintaan dan kehormatan terhadap bangsa sendiri. Atas dasar itu, para pemuda dapat melakukan sesuatu yang terbaik bagi bangsanya seperti halnya belajar dengan tekun, mentaati peraturan, mencintai produk dalam negeri, dan lain sebagainya yang tidak merugikan diri sendiri, orang lain 
dan termasuk juga negeri ini. Maka, dengan hal itu dapat dapat keutuhan persatuan bangsa, dan meningkatkan martabat bangsa dihadapan dunia. ${ }^{32}$

Untuk menumbuhkan karakter pemuda bangsa yang memiliki semangat juang yang tinggi bagi negaranya, maka dapat dilakukan melalui kebiasaan-kebiasaan baik yang akan melahirkan sebuah karakter dalam diri seseorang. Karakter yang tidak bisa datang dengan sendirinya membutuhkan kebiasaan-kebiasaan yang sengaja dibentuk dan dibangun dengan sadar dan sengaja. Untuk menumbuhkan karakter tentu tidak akan terlepas dari elemen-elemen disekitarnya, seperti halnya lingkungan keluarga, sekolah, dan masyarakat. Dalam dunia pendidikan kita mengenalnya dengan istilah Tri Pusat Pendidikan. Ketiganya saling berhubungan antara satu dengan yang lainnya dalam membantu proses tercapainya tujuan belajar ${ }^{33}$.

Agar tercapai sebuah tujuan pendidikan tentu perlu adanya perencanaan yang baik dan berkelanjutan. Salah satu komponen penting yang harus ada dalam lembaga pendidikan ialah kurikulum yang akan dijadikan rujukan untuk menentukan isi pengajaran, proses mekanisme pendidikan, tolak ukur keberhasilan dan kualitas hasil pendidikan ${ }^{34}$.

Pondok Pesantren Nurul Jadid Paiton probolinggo memiliki kurikulum mandiri yang menjadi ciri khas dan membedakannya dengan lembaga pendidikan pada umumnya. Kurikulum yang dikenal dengan sebutan tiga lima yakni, Trilogi dan Panca Kesadaran santri yang dipadukan kedalam sebuah struktur kurikulum dengan menambahkan fokus karakter pada perangkat pembelajaran yang isinya adalah tiga lima (Trilogi dan Panca kesadaran santri) tersebut.

Nilai-nilai yang telah ditanamkan oleh pendiri pondok pesantren Nurul Jadid, Paiton, Probolinggo berupa "Trilogi Santri" sebagai falsafat hidup dan menjadi pegangan bagi seluruh penghuni pesantren dan diterapkan di segala lini kehidupan. Hal tersebut menjadi salah satu landasan bagi setiap santri untuk memiliki sikap nasionalisme. Agar rasa cinta terhadap bangsa dan negaranya semakin kukuh, ada beberapa strategi yang dilakukan oleh pihak pesantren Nurul Jadid dalam rangka membangun kesadaran berbangsa dan bernegara santri, yakni:

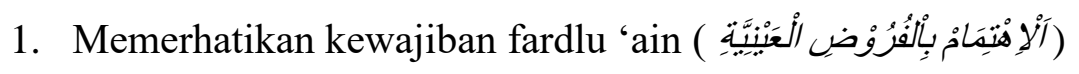

Manusia yang bertakwa adalah manusia yang menjalankan perintah serta menjauhi larangan-Nya. Seorang muslim yang baik tentunya setiap kali akan melakukan sesatu akan berusaha melakukan perbuatan-perbuatan yang

${ }^{32}$ Amalia Irfani, "NASIONALISME BANGSA DAN MELUNTURNYA SEMANGAT BELA NEGARA," 1961, 135-45.

${ }^{33}$ Zulriska Iskandar, Psikologi Lingkungan: Teori Dan Konsep (PT. Refika Aditama, 2012). h. 18 .

${ }^{34}$ S. Nasution, Kurikulum Dan Pengajaran, 2nd ed. (Jakarta: Bumi Aksara, 1995). h. 13. 
didasarkan pada nilai-nilai Islam. ${ }^{35}$ Sebagai manusia tentu kita tidak akan terlepas dari tugas pokok di dunia, sebagai Abdu Allah (Hamba Allah) dan sebagai khalifatullah (wakil allah di bumi sebagai pengelola semesta). Sebagai hamba Allah tentu manusia diharapkan untuk menyembah, mengabdikan diri hanya kepada Allah semata. Dan sebagai Khalifatullah, para manusia diharapkan dapat mengelola, memelihara dan memakmurkan alam semesta dengan sebaik-baiknya ${ }^{36}$.

Seperti halnya dalam Al-Qur'an surat An-Nisa' ayat 59 menjelaskan tentang sebagai seorang hamba harus mengabdi kepada Allah, patuh kepada Rasulullah, dan ulul $\mathrm{amri}^{37}$

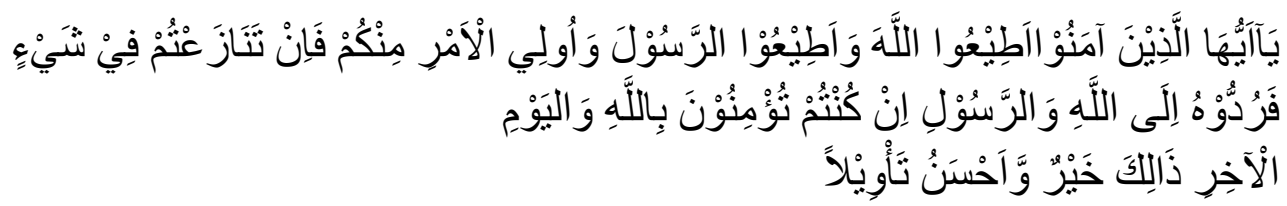

Artinya:

Hai orang-orang yang beriman, taatilah Allah dan taatilah Rasul (nya), dan ulil amri di antara kamu. Kemudian jika kamu berlainan pendapat tentang sesuatu, Maka kembalikanlah ia kepada Allah (Al Quran) dan Rasul (sunnahnya), jika kamu benar-benar beriman kepada Allah dan hari kemudian. yang demikian itu lebih utama (bagimu) dan lebih baik akibatnya. (QS. An-Nisa' [04]: 59)

Ayat tersebut menjelaskan bahwa umat Islam diperintahkan untuk patuh kepada Allah, Rasulullah, dan ulul amri. Di Indonesia sendiri yang menganut sistem demokrasi, patuh kepada ulil amri ditujukan kepada mereka para jajaran pemimpin (pemerintah). Kewajiban taat kepada pemimpin menjadi sangat penting untuk dapat melaksanakan syariat Islam. Adanya pemerintah itu karena ada sebuah badan yakni kerajaan atau negara disini yang pastinya berhubungan erat antara ulil amri dengan negara. Karena hal itu, kita di tuntut untuk taat terhadap pemerintah.

Syekh Ali ash-Shabuni menjelaskan bahwa patuh terhadap pemerintah bersifat wajib. ${ }^{38}$ Oleh karenanya rakyat harus mematuhi peraturan-peraturan yang telah diatur dalam UUD dan telah ditetapkan oleh pemerintah. Sehingga siapapun yang melanggar aturan tersebut tentunya akan mendapat hukuman sesuai dengan undang-undang yang berlaku dan tentunya akan mendapat dosa.

Kewajiban terhadap pemerintah ini tidak bersifat permanen, hal ini disebabkan karena banyak kebijakan yang ditetapkan keluar dari tatanan syariat. Dalam ayat tersebut perintah patuh kepada Allah menggunakan sighat amar, begitu juga terhadap Rasulullah, sedangkan terhadap pemerintah hanya menggunakan Athaf Wawu, sehingga dapat

${ }^{35}$ Muhammad Mushfi El Iq Bali and Mohammad Fajar Sodik Fadli, Implementasi Nilai-Nilai Pendidikan Pesantren Dalam Meningkatkan Ketahanan Mental Santri, PALAPA: Jurnal Studi Keislaman Dan Ilmu Pendidikan, vol. 7, 2019, https://doi.org/10.36088/palapa.v7i1.164.

${ }^{36}$ RI, Al-Qur'an Hafalan Dan Terjemahannya.

${ }^{37}$ RI. h. 87.

${ }^{38}$ Muhammad 'Ali Al-Sabuniy, Safwah At-Tafasir Juz 1 (Makkah: Darush-Shabuni, 1981). h. 285 . 
disimpulkan bahwa rakyat dapat mematuhi kebijakan dari pemerintah jika peraturan yang ditetapkan tidak keluar dari kaidah syariat (Allah Swt dan Rasullullah Saw).

Miniatur konsep memerhatikan kewajiban Fardlu 'ain di Pondok Pesantren Nurul Jadid dapat diimplentasikan melalui kesadaran santri terhadap patuh terhadap kiai. Kiai merupakan elemen penting yang tak bisa dihilangkan dalam lingkup Pondok pesantren sebagai suatu lembaga pendidikan. Sebagai warasatul al-anbiya' peran kiai tidak hanya memberikan pencerahan, pencerdasan dan membimbing umat dengan ajaran dan nilainilai Islam. Akan tetapi juga berperan untuk memperkokoh sendi-sendi etika, moral, dan spiritual kehidupan berbangsa dan bernegara. Kiai sebagai pemilik pesantren tidak hanya berdiam diri mengawasi para santri, tetapi kiai juga ikut berperan sebagai pengurus, sekaligus pengajar yang dibantu oleh ustaz atau ustazah sebagai pengurus pesantren. Karena pengurus merupakan tangan kanan kiai, maka peran pengurus sangat penting dalam kegiatan-kegiatan dipesantren..

Setiap santri harus memperhatikan kewajiban-kewajiban yang ditetapkan oleh allah dan juga ditetapkan oleh pesantren. Karena kewajiban seluruh santri butuh perhatian maka terbentuklah sebuah pengurus untuk memperhatikan dan sebagai rambu-rambu agar seluruh santri tetap menjaga kefardluan yang ditetapkan agama dan pesantren.

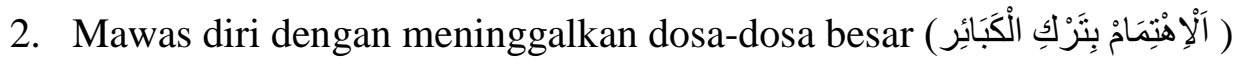

Mawas diri (self awareness) adalah sebuah sikap intropeksi diri sendiri. Mawas diri adalah bentuk dari sikap kewaspadaan seorang insan dalam menjaga ucapan dan perbuatan yang akan dilakukan atau yang sudah dilakukan. Mawas diri merupakan sikap menilai diri sendiri, melihat dan memeriksa diri sendiri secara terbuka agar di kemudian hari tidak mengulang kembali kesalahan yang sama. Dalam Islam dikenal dengan istilah muhasabah yang artinya Perhitungan atau intropeksi ${ }^{39}$.Dilansir dalam sebuah pengajian kitab di bulan ramadhan (Kitab Irsyadul Ibad) KH. Zuhri Zaini menuturkan bahwa "ketika perbuatan dosa masuk kepada hati kita, maka iman akan tersingkir". Mawas diri merupakan sikap pengontrolan, menghitung-hitung terhadap segala perbuatan dalam kehidupan sehari-hari, apakah hari ini perbuatan kita lebih baik dari sebelumnya atau sebaliknya lebih buruk. Maka dari itu, sikap mawas diri sangat diperlukan untuk mengendalikan sikap, perkataan dan tingkah laku dalam kehidupan sehari-hari. Sikap mawas diri biasanya dilakukan setahun sekali, sebulan sekali, seminggu sekali atau bahkan setiap hari. Sikap ini dilakukan atas kemauan sendiri yang dilakukan secara sadar tanpa adanya paksaan dari orang lain, dan dapat menimbulkan kedewasaan sikap terhadap perilaku seseorang.

Dalam hal meninggalkan dosa besar, salah satu trilogi tersebut tidak hanya menjadi pedoman bagi santri melainkan juga bagi santri alumni yang sudah terjun dalam masyarakat, salah satu contohnya bagi para alumni yang telah menggeluti dunia politik. Sebagai individu yang hidup di suatu negara, kita

${ }^{39}$ Ahmad Warson Munawir, Al-Munawir Kamus Arab-Indonesia (Yogyakarta: Pondok Pesantren Al-Munawir, 1984). h. 283 
terikat oleh aturan atau norma yang berlaku. Seorang pejabat negara bertanggung jawab terhadap tugas dan kewajibannya sesuai dengan jabatan yang diamanahkan. Serta tidak menyelewengkan amanah tersebut demi mendapatkan keuntungan pribadi. Seperti halnya seorang pejabat yang melakukan penggelapan uang (korupsi) negara untuk kepentingan pribadi. Hal ini menggambarkan bahwa pejabat tersebut mencerminkan perilaku yang tidak baik, meniadakan tanggung jawab yang diamanahkan oleh rakyat, yang mana hal tersebut selain merugikan negara juga membuat pelaku korupsi mendapatkan dosa.

Dari adanya trilogi santri yang kedua, dapat menjadi rambu-rambu atau pembatas bagi para santri yang menggeluti dunia politik untuk tidak melakukan perbuatan dosa besar seperti halnya melakukan perbuatan korupsi atau mengambil sesuatu yang bukan menjadi haknya.

Miniatur pembentukan karakter mawas diri meninggalkan dosa besar, bagaimana seorang santri mampu mematuhi seluruh peraturan yang berlaku di pondok pesantren, hal tersebut sebagai bentuk kesadaran santri dalam menjauhi hal-hal yang dilarang syari'at sekecil apapun itu. Karena, apabila dalam diri santri telah mempunyai kesadaran untuk meninggalkan dosa-dosa kecil, tidak menutup kemungkinan seorang santri juga mampu menjauhkan dirinya dari dosa-dosa besar.

3. Berbuat baik kepada Allah dan makhluk ( حُسنْ الَْدَبَ مَعَ اللَهِهَ )

Allah Swt menciptakan manusia sebagai makhluk social. Hal inilah yang menyebabkan manusia tidak bisa hidup secara individu (saling membutuhkan antara manusia yang satu dengan yang lainnya). Manusia diperintah untuk beribadah kepada-Nya, disamping itu manusia juga diamani memelihara hubungan baik serta hak terhadap sesama. KH. Achmad Siddiq pimpinan Pondok Pesantren as-Siddiqiyah Jember merumuskan konsep persaudaraan, yakni persaudaraan antara sesama Muslim (ukhuwah islamiyyah), persaudaraan antar sesama anak bangsa (ukhuwah wathaniyyah), dan persaudaraan antar sesama manusia (ukhuwah basyariyah). ${ }^{40}$ Konsep Ukhuwah Wathaniyah merupakan salah satu yang diterapkan dilingkungan pesantren. Konsep Persaudaraan sebangsa dan senegara (Ukhuwah Wathaniyah) merupakan ruh bagi cinta tanah air yang berlandaskan nilai-nilai Islam. Para kiai pesantren menyadari bangsa Indonesia memiliki kemajemukan yang terdiri dari suku, bahasa, adat-istiadat dan agama serta kepercayaan yang berbeda-beda, tetapi tetap bersaudara (Bhineka Tunggal Ika) oleh Gus Dur diistilahkan dengan kosmopolitanisme pesantren.Kepemimpinan pesantren yang diperankan kiai sebagai figur utama bagi santri di lingkungan pesantren, merupakan teladan (role model), serta mengisi seluruh waktunya dengan beribadah dan untuk berbuat kebaikan, membuat masyarakat percaya bahwa kiai memiliki karakter sangat mulia serta dekat sekali dengan Tuhan. Perannya

${ }^{40}$ Lanny Oktavia, Pendidikan Karakter Berbasis Tradisi Pesantren Kumpulan Bahan Ajar. h. 32. 
dilakukan secara terus menerus kepada para santrinya berupa transformasi nilai, sehingga dapat ditiru para santri.

Sistem pendidikan 24 jam dipesantren, memudahkan para kiai, para ustad dan pengurus untuk mengawasi perilaku para santri. Para santri ditanamkan nilainilai religiositas seperti persaudaraan, tolong menolong, persatuan, menuntut ilmu, ikhlas, perjuangan, tawakkal (pasrah kepada Allah), patuh kepada Tuhan, Rasul, ulama atau kiai untuk mandiri, saling tolong menolong antar sesama, kepedulian yang tinggi, serta berperilaku sederhana. Sebagai upaya menambah semangat para santri, para ustad dan pengurus akan memberikan reward bagi yang berperilaku baik, sedangkan yang berperilaku negatif akan diberi ta'zir (hukuman).Adab Ukhuwah dilingkungan pesantren menjadi perhatian utama, melihat kondisi para santri yang sama-sama jauh dari keluarga membuat mereka saling menjaga antara satu dengan yang lainnya. Hal inilah yang melatarbelakangi minimnya tindakan kriminal dan radikal di kalangan santri. Maka, sangat jarang bahkan tidak pernah kita temukan santri bertawuran antar santri. Dari itu, pendidikan pesantren sebagai pusat pembentukan karakter muslim berakhlak mulia dan menjunjung tinggi persatuan, harus lebih mengintensifkan diri dalam pembangunan karakter muslim santun. Sebagaimana ungkapan K.H. Zuhri Zaini ${ }^{41}$ terkait hakikat santri:

"hakikat santri adalah wajah Islam nusantara. Santri adalah kiblat keislaman yang damai, ramah, sejuk dan pemersatu dalam kehidupan berbangsa dan bernegara bahkan diantara sesama manusia." 42

Hal inilah yang menjadi ciri khas pendidikan pesantren yang tidak tergantikan. Melalui kiai, santri belajar betapa akhlak lebih utama daripada ilmu pengetahuan yang didapat.Trilogi yang ketiga, dapat diterapkan oleh santri dengan menjaga hubungan, baik kepada Allah ataupun kepada sesama. Santri tidak hanya dilatih untuk menjaga hubungan baik dengan tuhanNya, melainkan juga dilatih untuk memiliki sifat empati dan saling menghormati satu sama lain, Seperti halnya, ketika ada salah satu teman yang sakit maka dibawalah ke klinik untuk diperiksa, kegiatan bersih-bersih wilayah setiap pagi dan sore, melaksanakan salat dengan berjamaah dan lain-lain. Hal tersebut diwujudkan sebagai bentuk kesadaran santri dalam berbangsa

Penuturan KH. Zuhri Zaini tentang upaya pesantren dalam menumbuhkan kesadaran berbangsa dan bernegara melalui Trilogi Santri:

Berupaya sungguh-sungguh untuk melaksanakan kewajiban terutama yang fardhu ain, berupaya dengan sungguh-sungguh untuk menjauhi dosa-dosa terutama dosa besar dan menjaga adab dan tata karma baik kepada Tuhan dan kepada sesame makhluk. Tentu yang dimaksud kewajiban dalam Trilogi Santri bukan hanya kewajiban kepada Tuhan tapi juga kewajiban kepada sesama (sosial); termasuk juga wajib bela negara dan

${ }^{41}$ KH. Zuhri Zaini merupakan putra kelima dari pasangan KH. Zaini Mun'im dan Ny. Nafi'ah. Dilahirkan di Probolinggo pada 5 Oktober 1952. Saat ini beliau mengemban amanah sebagai Pengasuh ke IV pondok Pesantren Nurul Jadid Paiton Probolinggo sejak tahun 2000Sekarang.

${ }^{42}$ http://nuruljadid.net/profil diakses 25/12/2019 10.43 
menjaga kesatuan dan persatuan bangsa. Begitu juga dosa, tentu bukan hanya dosa kepada Tuhan tapi juga dosa kepada sesama (sosial). Begitu juga adab tata krama, dan akhlak, tentu tidak hanya kepada Tuhan tetapi juga kepada sesama, khususnya kepada sesama anak bangsa. Maka dengan akhlak dan adab yang baik, kerukunan, dan kedamaian yang menjadi pilar utama dari kesatuan dan persatuan bangsa. ${ }^{43}$

Selain dengan pengimplementasian Trilogi Santri, Pondok Pesantren Nurul Jadid Paiton Probolinggo juga menerapkan berbagai upaya dalam menumbuhkan kesadaran berbangsa dan bernegara.

1. Menanamkan kesadaran berbangsa dan bernegara

Penanaman kesadaran kepada para santri, bahwa negara yang merupakan rumah bersama bangsa (termasuk para santri) adalah anugerah Tuhan yang wajib disyukuri, dirawat, dan dijaga dari gangguan-gangguan yang bisa merusaknya baik yang datang dari luar maupun dari dalam. Sehingga, mereka bisa menghuni negeri ini dengan tenang dan damai.

2. Dilibatkan dalam kegiatan kenegaraan

Para santri di pesantren diikutkan kegiatan-kegiatan kenegaraan seperti upacara bendera untuk memperingati hari ulang tahun kemerdekaan Negara RI pada setiap tanggal 17 Agustus (tim PASKIBRA), kepramukaan, santri patriot, santri pelopor, dan lain-lain ${ }^{44}$.

a. Tim PASKIBRA (pasukan pengibar bendera)

Tim Paskibra merupakan para santri (khususnya tingkat SLTA) yang memiliki bakat dan kemauan serta lolos dalam seleksi tim paskibraka. Tim paskibraka ini nantinya yang akan melaksanakan prosesi pengibaran sang saka merah putih, dan prosesi penurunan bendera.

b. PRAMUKA

Wadah untuk melatih kemandirian santri yang berbentuk kepanduan dengan membentuk Gudep pada setiap satuan pendidikan.

c. Santri Patriot

Santri Patriot adalah wadah bagi santri-mahasiswa yang diorientasikan untuk menyiapkan kader pengurus pesantren yang diperbantukan pada satuan kerja kepengurusan Pesantren.

d. Panji Pelopor

Panji pelopor adalah wadah pembinaan santri yang dididik menjadi pengelola even organizer dengan materi keprotokoleran, kehumasan, tata acara dan tata boga. Dalam tugasnya membantu pengurus dalam menyiapkan even-even dan penerimaan tamu-tamu pesantren.

${ }^{43}$ Wawancara dengan KH. Zuhri Zaini, pada tanggal 20 Maret 2020 di Pondok Pesantren Nurul Jadid Paiton probolinggo.

${ }^{44}$ Dokumen Pondok Pesantren Nurul Jadid, Probolinggo: 2020. 


\section{Mengadakan seminar-seminar kebangsaan}

Seminar kebangsaan adalah pertemuan yang dipimpin oleh seorang moderator, dengan membahas suatu permasalahan dan mendatangkan pembicara yang ahli dibidangnya, untuk membahas suatu permasalahan yang berkaitan dengan kebangsaan. Dalam hal ini, Pondok Pesantren Nurul Jadid mendatangkan para tokoh-tokoh yang sudah mumpuni dibidangnya. Tujuan diadakannya seminar kebangsaan, guna menambah wawasan/pengetahuan atau sesuatu yang baru kepada seluruh santri di pondok pesantren Nurul Jadid yang nantinya dapat dikembangkan dan diimplementasikan kembali dalam kehidupan sehari-hari. Selain untuk menambah wawasan para santri dengan diadakannya seminar kebangsaan diharapkan dapat menggugah semangat dan menumbuhkan kesadaran para santri akan pentingnya menjaga kesatuan dan persatuan bangsa ini.

Trilogi Santri merupakan fondasi dalam pengembangan kualitas keberagamaan santri, baik yang berkaitan dengan Allah maupun berkaitan sesama manusia, bahkan dengan semua makhluk Allah. Penetapan al furûdhul 'ainiyyah dan tarki al-kabâir, merupakan standart minimal, yang harus menjadi perhatian dan komimen santri dalam menjalankan kewajiban agama, sehingga melalui komitmen tersebut, para santri diharapkan mampu terus menyempurnakan amaliah keagamaannya

Tentu bila para santri melaksanakan kewajiban-kewajibannya baik kepada Tuhan maupun kepada sesama, dan juga bila para santri menghindari perbuatan dosa dan salah, baik kepada Tuhan maupun kepada sesama, disamping bila akhlak mereka (para santri) terbina dengan baik, maka pasti kesadaran berbangsa dan bernegara akan tumbuh pada diri mereka, yaitu dengan melaksanakan kewajiban mereka kepada negara dan bangsanya dalam bentuk kecintaan, kepedulian, semangat untuk merawat, menjaga dan membela bangsa dan negaranya.

Para santri Pondok Pesantren Nurul Jadid Paiton Probolinggo diharapkan aktif berjuang di masyarakat dengan passion masing-masing. sebagai bagian dari bangsa dan warga Negara Indonesia, kita termasuk para pemuda dan santri hendaknya ikut memelihara, merawat, dan menjaga Negara Kesatuan Republik Indonesia yang merupakan rumah kita bersama. Karena bila Negara ini baik maka kita akan bisa menghuninya dengan nyaman. Sebaliknya bila Negara ini rusak atau kacau, maka kita sebagai penghuninya tidak akan merasa nyaman, baik ketika beribadah, bekerja maupun ketika sedang beristirahat atau bersantai. Dan termasuk upaya menjaga negeri ini adalah memelihara dan merawat lingkungan alamnya dengan melestarikannya, maupun lingkungan sosialnya dengan cara menjaga kerukunan persatuan dan kesatuan bangsa. Santri diharapkan tidak hanya menjadi tokoh besar akan tetapi pasif dalam berjuang. ${ }^{45}$

${ }^{45}$ Akmal Mundiri and Afidatul Bariroh, "Trans Internalisasi Pembentukan Karakter Melalui Trilogi Dan Panca Kesadaran Santri,” IQRA ‘ (Jurnal Kajian Ilmu Pendidikan) 3, no. 1 (2018): 24-55. 


\section{SIMPULAN}

Berdasarkan uraian di atas dapat disimpulkan bahwa untuk menumbuhkan kesadaran santri dalam berbangsa dan bernegara, pesantren memiliki prinsip yang dapat dijadikan pedoman bagi santri. Prinsip trilogi santri yang terdapat di pesantren Nurul Jadid sebagai aset pemikiran kyai Zaini Mun'im dalam membentuk dan mewujudkan santri yang tidak hanya berkiprah sebagai cendekiawan Islam, melainkan santri dituntut juga memiliki jiwa yang sadar akan berbangsa dan bernegara.

Implementasi trilogi santri diwujudkan melalui beberapa pembisaan-pembiasaan kegiatan santri yang akan menumbuhkan kesadaran santri dalam berbangsa dan bernegara. Pertama, Setiap santri harus memperhatikam kewajiban-kewajiban yang ditetapkan oleh allah dan juga ditetapkan oleh pesantren, dimana santri memiliki perhatian khusus atas apa yang telah dibebankan dan harus dijadikan sebagai kewajiban fardhu 'ainnya. Kedua, trilogi kedua dapat dilihat melalui kesadaran santri untuk mematuhi seluruh peraturan pesantren. Ketiga, cerminan yang dapat dilihat dari trilogi yang terakhir ialah kegiatan gotong royong ketika melaksanakan kegiatan santri, contoh kecilnya ialah ketika santri melakukan bersih-bersih wilayah. Upaya-upaya yang dilakukan pesantren untuk menumbuhkan kesadaran berbangsa dan bernegara ialah dengan menumbuhkan kesadaran dalam pribadi santri akan pentingnya menjaga kesatuan dan persatuan bangsa, dilibatkan dalam kegiatan kenegaraan, dan mengadakan seminarseminar dengan mengundang para tokoh yang sudah mumpuni dibidangnya.

\section{DAFTAR PUSTAKA}

Al-Sabuniy, Muhammad 'Ali. Safwah At-Tafasir Juz 1. Makkah: Darush-Shabuni, 1981.

Amin, M. Masyhur. NU \& Ijtihad Politik Kenegaraannya. Yogyakarta: Al-Amin Press, 1996.

Dhofier, Zamankhari. TRADISI PESANTREN (Studi Pandangan Hidup Kyai Dan Visinya Mengenai Masa Depan Indonesia). Jakarta: LP3ES, anggota Ikapi, 2015.

Fahham, A Muchaddam. "Pendidikan Karakter Di Pesantren (Character Education in Islamic Boarding School).” Aspirasi 4, no. 1 (2013): 29-45.

Galba, Sindu. Pesantren Sebagai Wadah Komunikasi. 2nd ed. Jakarta: Rineka Cipta, 1995.

Hartoyo, H. Agung. "Menggugah Kesadaran Nasional Mempengarui Kebhinekaan Indonesia.” Jurnal Pendidikan Sosiologi Dan Humaniora 1, no. 2 (2019): 132-47.

Iq Bali, Muhammad Mushfi El, and Mohammad Fajar Sodik Fadli. Implementasi NilaiNilai Pendidikan Pesantren Dalam Meningkatkan Ketahanan Mental Santri. 
PALAPA: Jurnal Studi Keislaman Dan Ilmu Pendidikan. Vol. 7, 2019. https://doi.org/10.36088/palapa.v7i1.164.

Irfani, Amalia. "NASIONALISME BANGSA DAN MELUNTURNYA SEMANGAT BELA NEGARA," 1961, 135-45.

Iskandar, Zulriska. Psikologi Lingkungan: Teori Dan Konsep. PT. Refika Aditama, 2012.

Islam, Syaiful, Hasan Baharun, Chusnul Muali, Moh Idil Ghufron, Mushfi el Iq Bali, Mualim Wijaya, and Ismail Marzuki. "To Boost Students ' Motivation and Achievement through Blended Learning." Journal of Physics: Conf. Series 1114, 2018, 1-11.

Jamal, Nur. "Transfoormasi Pendidikan Pesantren Dalam Pembentukan Kepribadian Santri." Tarbiyatuna: Jurnal Pendidikan Islam 8, no. 2 (2015): 64-100.

Jamali. Kaum Santri Dan Tantangan Kontemporer", Dalam Pesantren Masa Depan: Wacana Pemberdayaan Dan Transformasi Pesantren, Ed. Said Aqiel Siradj. Bandung: Pustaka Hidayah, 1999.

“Kamus Besar Bahasa Indonesia Online,” n.d. https://www.kbbi.web.id/negara.

Kristiawan, Muhammad, and Yeni Wulandari. "Strategi Sekolah Dalam Penguatan Pendidikan Karakter Bagi Siswa Dengan Memaksimalkan Peran Orang Tua." Jurnal Manajemen, Kepemiminan, Dan Supervisi Pendidikan (JMKSP) 2, no. 2 (2017): 290-303.

Lanny Oktavia, Dkk. Pendidikan Karakter Berbasis Tradisi Pesantren Kumpulan Bahan Ajar. 1st ed. Jakarta: Rumah Kitab, 2014.

Munawir, Ahmad Warson. Al-Munawir Kamus Arab-Indonesia. Yogyakarta: Pondok Pesantren Al-Munawir, 1984.

Mundiri, Akmal, and Afidatul Bariroh. "Trans Internalisasi Pembentukan Karakter Melalui Trilogi Dan Panca Kesadaran Santri." IQRA' (Jurnal Kajian Ilmu Pendidikan) 3, no. 1 (2018): 24-55.

Murod, Abdul Choliq. "NASIONALISME " DALAM PESPEKTIF ISLAM." Jurnal Sejarah CITRA LEKHA XVI, no. 2 (2011): 45-58.

Nasrullah, Feri Jon. "Pendidikan Karakter Pada Anak Dan Remaja." Jurnal Seminar Psikologi Dan Kemanusiaan, 2015, 483-86.

Nasution, S. Kurikulum Dan Pengajaran. 2nd ed. Jakarta: Bumi Aksara, 1995.

RI, Depatemen Agama. Al-Qur'an Hafalan Dan Terjemahannya. 1st ed. Jakarta: almahira, 2015. 
Rizal, Saifur. "Servant Leadership Dalam Implementasi Nilai-Nilai Trilogi Dan Panca Kesadaran Santri." Journal EVALUASI 3, no. 2 (2019): 162. https://doi.org/10.32478/evaluasi.v3i2.251.

Shihab, M. Quraish. Wawasan Al-Qur'an Tafsir Tematik Atas Pelbagai Persoalan Umat. Bandung: Mizan Pustaka, 1996.

Sudjanadan Ibrahim, Nana. Penelitian Dan Penilaian Pendidikan. 2nd ed. Bandung: Sinar Baru Algesindo, 2001.

Suib, M Syaiful. "ISLAM DAN INDONESIA MENURUT KH . ZAINI MUN' IM : Wawasan Tentang Islam.” At-Turas V, no. 2 (2018): 263-83.

Sukamto. Kepemimpinan Kiai Dalam Pesantren. Jakarta: Pustaka LP3ES, 1999.

Syaifullah, and Totok Suyanto. "Aktualisasi Nilai-Nilai Multikultural Di Pondok Pesantren.” Jurnal Kajian Moral Dan Kewarganegaraan 3, no. 2 (2014): 1061-75.

Syarbaini, Syahrial. Pendidikan Pancasila Di Perguruan Tinggi Implementasi Nilai-Nilai Karakter. Bogor: Ghalia Indonesia, 2014.

Wahyuni, Astri, Ayu Aji, Wedaring Tias, and Budiman Sani. "Peran Etnomatematika Dalam Membangun Karakter Bangsa:" Penguatan Peran Matematika Dan Pendidikan Matematika Untuk Indonesia Yang Lebih Baik, no. 1 (2013): 111-18.

Wulandari, Y., and M. Kristiawan. "Strategi Sekolah Dalam Penguatan Pendidikan Karakter Bagi Siswa Dengan Memaksimalkan Peran Orang Tua.” JMKSP (Jurnal Manajemen, Kepemimpinan, Dan Supervisi Pendidikan) 2, no. 2 (2017): 290-302.

Zuhry, Ach. Dhofir. Peradaban Sarung = Veni, Vidi, Santri. Jakarta: Elex Media Komputindo, 2018. 